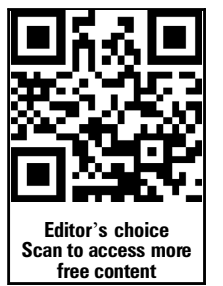

Department of Ophthalmology, University of Kiel, University Medical Center, Kiel, Germany

Correspondence to Professor Alexa Klettner, Department of Ophthalmology, University of Kiel, University Medical Center, Arnold-HellerStr. 3, Kiel 24105, Germany; aklettner@auge.uni-kiel.de

Received 17 February 2014 Revised 26 June 2014 Accepted 27 June 2014 Published Online First 17 July 2014
CrossMark

To cite: Klettner $\mathrm{A}$, Tahmaz N, Dithmer $\mathrm{M}$, et al. Br J Ophthalmol

2014;98:1448-1452.

\title{
Effects of aflibercept on primary RPE cells: toxicity, wound healing, uptake and phagocytosis
}

\author{
Alexa Klettner, Nihat Tahmaz, Michaela Dithmer, Elisabeth Richert, Johann Roider
}

ABSTRACT

Background/aim Anti-VEGF treatment is the therapy of choice in age-related macular degeneration, and is also applied in diabetic macular oedema or retinal vein occlusion. Recently, the fusion protein, aflibercept, has been approved for therapeutic use. In this study, we investigate the effects of aflibercept on primary RPE cells. Methods Primary RPE cells were prepared from freshly slaughtered pigs' eyes. The impact of aflibercept on cell viability was investigated with MTT and trypan blue exclusion assay. The influence of aflibercept on wound healing was assessed with a scratch assay. Intracellular uptake of aflibercept was investigated in immunohistochemistry and its influence on phagocytosis with a phagocytosis assay using opsonised latex beads.

Results Aflibercept displays no cytotoxicity on RPE cells but impairs its wound healing ability. It is taken up into RPE cells and can be intracellularly detected for at least 7 days. Intracellular aflibercept impairs the phagocytic capacity of RPE cells.

Conclusions Aflibercept interferes with the physiology of RPE cells, as it is taken up into RPE cells, which is accompanied by a reduction of the phagocytic ability. Additionally, it impairs the wound healing capacity of RPE cells. These effects on the physiology of RPE cells may indicate possible side effects.

\section{INTRODUCTION}

Age-related macular degeneration (AMD) is the most common cause for legal blindness in the developed countries. Intravitreal application of anti-VEGF molecules is the gold standard for treatment the exudative form of this disease. ${ }^{1}$ In the clinic, different VEGF antagonists are currently in use, the approved ranibizumab, the off-label bevacizumab, and the recently approved aflibercept. ${ }^{2-4}$ For effective treatment, repeated intravitreal injections are needed, and, for ranibizumab, best results were obtained by monthly injections, even though in clinical practice, other treatment regiments are usually followed. ${ }^{5}$ Additionally, in exudative AMD, the treatment may have to be continued for several years, as the cessation of anti-VEGF treatment may result in the reoccurrence of choriodal neovascularisations, bleeding and vision loss. ${ }^{6}$

The currently used anti-VEGF molecules, bevacizumab, ranibizumab and aflibercept, differ not only in their VEGF binding affinity, but also in their molecular structure. Bevacizumab is a humanised murine full-length antibody against VEGF-A with a molecular weight of $149 \mathrm{kDa}$, while ranibizumab is a high affinity Fab-fragment against VEGF-A with a molecular weight of $48 \mathrm{kDa}$, lacking the Fc-fragment. Aflibercept is a fusion protein with a molecular weight of $115 \mathrm{kDa}$, composed of the 2nd Ig domain of the VEGFR-1 and the 3rd Ig domain of the VEGFR-2 connected to an Fc-fragment. ${ }^{7}$ These molecular differences may result in different effects on retinal cells.

We have previously investigated and compared the effect of ranibizumab and bevacizumab on RPE cells, finding apparent differences. Bevacizumab, but not ranibizumab, is taken up by and stored in RPE cells for at least 7 days. The presence of intracellular bevacizumab impairs the phagocytic function of RPE cells. ${ }^{8}{ }^{9}$ An uptake of bevacizumab by endothelial cells has recently been reported. ${ }^{10}$

In this study, we investigated the effect of aflibercept on RPE cells, regarding toxicity, wound healing, cellular uptake and phagocytosis.

\section{MATERIAL AND METHODS \\ Primary RPE isolation and culture}

Porcine RPE cells were isolated as previously described. ${ }^{11}$ In brief, porcine eyes obtained from the local abattoir were cleaned of adjacent tissue and immersed briefly in antiseptic solution (betaisodona, Mundipharma, Limburg, Germany). The anterior part of the eye was removed, as well as lens, vitreous and retina. In each eye cup, trypsin was added, and incubated for $10 \mathrm{~min}$ at $37^{\circ} \mathrm{C}$. Trypsin solution was removed and substituted with trypsin-EDTA for $45 \mathrm{~min}$ at $37^{\circ} \mathrm{C}$. RPE cells were gently pipetted off the choroid, collected in media and washed. Cells were cultivated in Dulbecco's modified Eagle's medium (DMEM) supplemented with penicillin/ streptomycin (1\%), HEPES $(25 \mathrm{mM})$, sodiumpyruvat $(110 \mathrm{mg} / \mathrm{mL})$, and $10 \%$ fetal calf serum (Linaris GmbH, Wertheim-Bettingen, Germany).

\section{Treatment of cells}

Confluent primary porcine RPE cells of second or third passage were treated with different concentrations of bevacizumab $(125 \mu \mathrm{g} / \mathrm{mL}, 250 \mu \mathrm{g} / \mathrm{mL})$, ranibizumab $(125 \mu \mathrm{g} / \mathrm{mL})$ or aflibercept $(125 \mu \mathrm{g} / \mathrm{mL}$, $500 \mu \mathrm{g} / \mathrm{mL})$ for various time periods $(1 \mathrm{~h}, 4 \mathrm{~h}, 24 \mathrm{~h}$, 3 days, 5 days, 7 days). Concentration and time frame were dependent on the respective experiment. Medium was changed after the third day of incubation without addition of the respective VEGF inhibitor.

\section{MTT-assay}

Cell viability in cell culture after $24 \mathrm{~h}$ and 7 days of aflibercept incubation was tested with methyl thiazolyl tetrazolium (MTT) assay as described elsewhere with modifications. ${ }^{12}$ Briefly, MTT was dissolved $0.5 \mathrm{mg} / \mathrm{mL}$ in DMEM without phenol red (PAA). Cells were washed three times with PBS and incubated with MTT at $37{ }^{\circ} \mathrm{C}$ for $2 \mathrm{~h}$. MTT was discarded and dimethyl sulfoxide was added to 
the cells. The tissue plates were shaken at $200 \mathrm{rpm}$ for $5 \mathrm{~min}$. Adsorption was measured at $555 \mathrm{~nm}$ with Elx800 (BioTek, Bad Friedrichshall, Germany).

\section{Trypan blue exclusion assay}

After stimulation with aflibercept for $24 \mathrm{~h}$ or 7 days, cell viability was determined by trypan blue exclusion assay as previously described. ${ }^{13}$ Briefly, cells were detached with trypsin-EDTA, the pellet was resuspended in PBS and the number of viable cells were assessed in a Neubauer's cell chamber, using trypan blue as non-viability stain. The result was related to the number of cells of an untreated control which was considered $100 \%$.

\section{Scratch-assay}

The scratch-assay determines the migratory ability of the cells. Primary RPE cells were seeded in a 12-well plate. Three wounds were scratched in the confluent cell layer with a toothpick and the cells were washed with PBS to remove detached cells. Medium without phenol red (Dulbecco's modified Eagle's medium) supplemented with penicillin/streptomycin (1\%), HEPES $(25 \mathrm{mM})$, sodium-pyruvate $(110 \mathrm{mg} / \mathrm{mL})$, and $10 \%$ fetal calf serum) was added and microscopic bright field pictures of three precise spots were taken and the coordinates noted (Zeiss, Jena, Germany). Aflibercept, ranibizumab, or bevacizumab, respectively, was added to the wells at indicated concentrations. Twenty-four hours after stimulation, another picture was taken at the same coordinates. To analyse the migration of the cells, the stimulation was conducted in duplicate and three pictures per well were made. The gap size of the wound was measured with AxioVision Rel.4.8. (Zeiss, Jena, Germany), and the percentages of coverage of the wounds were evaluated. Complete coverage was defined as $100 \%$.

\section{Immunocytochemistry}

Immunocytochemistry of RPE cells was conducted as previously described with modifications. ${ }^{14}$ Briefly, cells were treated with $125 \mu \mathrm{g} / \mathrm{mL}$ or $500 \mu \mathrm{g} / \mathrm{mL}$ aflibercept. After the indicated time periods, cells were briefly washed with PBS $0.1 \%$ azide, and fixed in $2.5 \%$ paraformaldehyde at room temperature followed by acetone-ethanol for $10 \mathrm{~min}$ at $-20^{\circ}$. Cells were blocked with $0.1 \%$ BSA $0.2 \%$ glycine in TBS, washed and incubated with goat anti-human antibodies coupled with AlexaFluor 555 (Invitrogen, Karlsruhe, Germany) at $37^{\circ}$ for $1 \mathrm{~h}$. Nuclear staining was performed using Hoechst stain. Cells were washed and mounted using Slow Fade Mounting Medium (Invitrogen). Stained cells were analysed with the Axio Imager Z1 (Zeiss, Jena, Germany).

Figure 1 Toxicity of $500 \mu \mathrm{g} / \mathrm{mL}$ aflibercept after $24 \mathrm{~h}$ and 7 days. Confluent primary porcine RPE cells of second or third passage were treated with aflibercept at a concentration of $500 \mu \mathrm{g} / \mathrm{mL}$ for $24 \mathrm{~h}$ and 7 days, respectively. Toxicity was evaluated in trypan blue exclusion assay and methyl thiazolyl tetrazolium (MTT) assay ( $n=6$ for every assay). Aflibercept displayed no toxicity on RPE cells, neither in trypan blue-exclusion assay $(A)$ nor in MTT assay (B). Significance was determined by Student $t$ test. $h=$ hours, $\mathrm{d}=$ days, afli=aflibercept, MTT=methyl thiazolyl tetrazolium.

\section{Phagocytosis assay}

Phagocytosis was investigated in an assay using FITC-labelled beads, treated with a crude extract of photoreceptor outer segments. The uptake was assessed in a fluorescence microscope, as previously described. ${ }^{14}$ Briefly, photoreceptor outer segments were prepared from porcine retina and used to opsonise FITC-labelled latex beads (diameter $1 \mu \mathrm{m}$ ) for $1 \mathrm{~h}$ at room temperature. Seven days after a single treatment with aflibercept $(500 \mu \mathrm{g} / \mathrm{mL})$ or bevacizumab $(250 \mu \mathrm{g} / \mathrm{mL})$, RPE cells of $2 \mathrm{nd}$ passage were treated with opsonised beads and incubated for $4 \mathrm{~h}$ at $37^{\circ} \mathrm{C}$. In this time frame, opsonised beads are readily taken up by RPE cells. ${ }^{14}$ Cellular uptake of beads was detected in fluorescence microscopy. For this, cells were fixed and prepared for fluorescence microscopy as described above, and eight pictures per slide were taken. Beads and nuclei of cells displaying intracellular aflibercept or bevacicumab, respectively, were counted, the ratio determined, and compared with untreated control.

\section{Statistics}

Each experiment was independently repeated at least three times. Graphs display mean and SD. Significance was evaluated with an unpaired, two-tailed Student $t$ test. A $p$ value of $\leq 0.05$ was considered significant.

\section{RESULTS}

\section{Toxicity of aflibercept}

Application of aflibercept at a concentration of $500 \mu \mathrm{g} / \mathrm{mL}$ for $24 \mathrm{~h}$ and 7 days, respectively, displayed no toxicity on RPE cells, neither in MTT-assay (24 h: $97.8 \pm 3.0 \%$; 7 days: $102.4 \pm 0.9 \%$ ) nor in trypan blue exclusion assay ( $24 \mathrm{~h}$ : $97.9 \pm 7.3 \%$; 7 days:

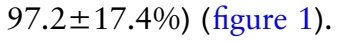

\section{Wound healing}

In the wound healing assay, we compared aflibercept, bevacizumab and ranibizumab at a concentration of $125 \mu \mathrm{g} / \mathrm{mL}$. Additionally, we assessed aflibercept and bevacizumab at their clinically relevant concentrations $(500 \mu \mathrm{g} / \mathrm{mL}$ and $250 \mu \mathrm{g} / \mathrm{mL}$, respectively). At a concentration of $125 \mu \mathrm{g} / \mathrm{mL}$, none of the tested reagents displayed a statistically significant effect on wound healing compared with control (control 74.2 $\pm 5.5 \%$ closure, aflibercept: $72.2 \pm 6.1 \%$ closure; bevacizumab 71.6 $\pm 5.0 \%$ closure; ranibizumab $79.3 \pm 6.3 \%$ closure). However, when clinically relevant concentrations were used, aflibercept and bevacizumab displayed a statistically significant effect on wound healing compared with control (control $87.3 \pm 8.4 \%$ closure, aflibercept $500 \mu \mathrm{g} / \mathrm{mL} 70.3 \pm 10.3 \%$ closure, $\mathrm{p}<0.01$; bevacizumab $250 \mu \mathrm{g} / \mathrm{mL} \quad 80.7 \pm 6.8 \%$ closure, $\quad \mathrm{p}<0.05)$ (figure 2). 
A $125 \mu \mathrm{g} / \mathrm{ml}$, scratch assays

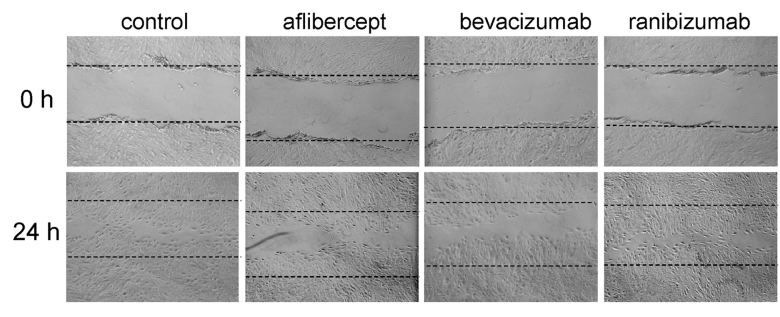

C Clinically relevant concentrations, scratch assays
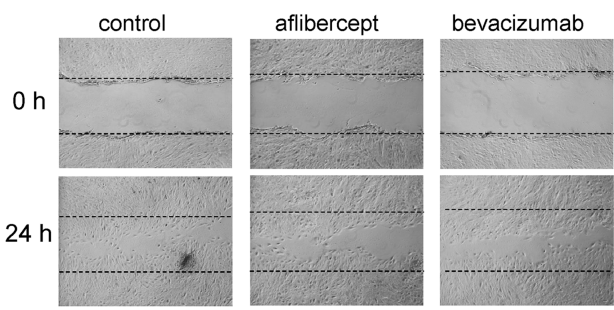

B $125 \mu \mathrm{g} / \mathrm{ml}$, quantification

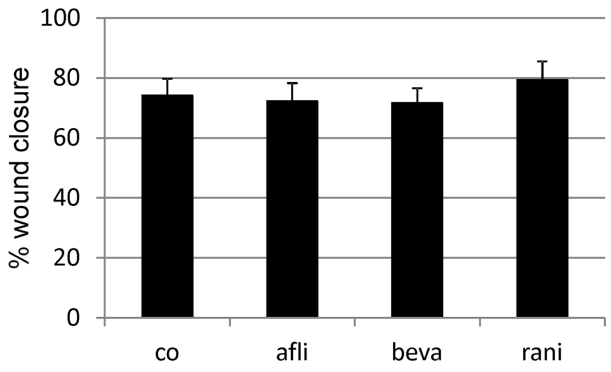

D Clinically relevant concentrations, quantification

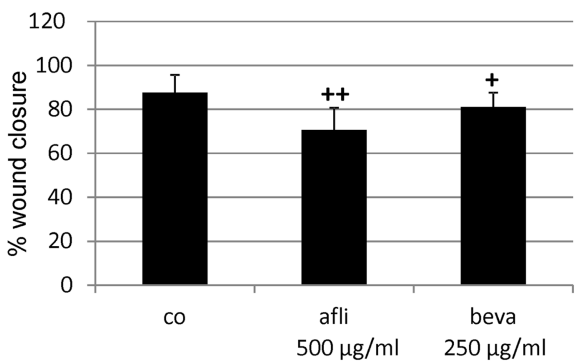

Figure 2 Wound healing assay. Migration ability was determined in a scratch assay where three wounds were scratched in the confluent RPE cell layer with a toothpick, microscopic bright field pictures were taken and the precise coordinates were reassessed after $24 \mathrm{~h}$ of stimulation with aflibercept, bevacizumab, or ranibizumab at indicated concentrations. Aflibercept, bevacizumab and ranibizumab at $125 \mu \mathrm{g} / \mathrm{mL}$, (A) exemplary scratch and (B) quantification ( $\mathrm{n}=5)$; clinical relevant concentrations of aflibercept $(500 \mu \mathrm{g} / \mathrm{mL})$ and bevacizumab $(250 \mu \mathrm{g} / \mathrm{mL})$, (C) exemplary scratch and $(D)$ quantification $(n=4)$. At a concentration of $125 \mu \mathrm{g} / \mathrm{mL}$, none of the tested reagents displayed a statistically significant effect on wound healing compared with control. At clinically relevant concentrations, aflibercept and bevacizumab displayed a statistically significant effect on wound healing compared with control. Significance was determined by Student $t$ test. ${ }^{\prime+1} p<0.05 ;^{{ }^{\prime++1}} p<0.01$. co=control, afli=aflibercept, beva=bevacizumab, rani=ranibizumab.

\section{Cellular uptake}

Aflibercept was found in RPE cells after $1 \mathrm{~h}$ of stimulation and was intracellularly seen for at least 7 days (latest time point tested). After $1 \mathrm{~h}$ of incubation, a vesicle-like distribution was seen, with some but not all cells affected. After 3 days of incubation, a netlike pattern was observed, but vesicles were still present. No difference in pattern or intensity was found for the application of $125 \mu \mathrm{g} / \mathrm{mL}$ or $500 \mu \mathrm{g} / \mathrm{mL}$ aflibercept (figure 3). Additionally, no statistical significant differences were found between the percentage of cells stained positive for aflibercept at $125 \mu \mathrm{g} / \mathrm{mL}$ and $500 \mu \mathrm{g} / \mathrm{mL}$ (cells stained positive for aflibercept: $1 \mathrm{~h}: 125 \mu \mathrm{g} / \mathrm{mL} 82.9 \%$ $\pm 15.2 \% ， 500 \mu \mathrm{g} / \mathrm{mL} \quad 84.9 \% \pm 8.9 \% ; 4 \mathrm{~h}: 125 \mu \mathrm{g} / \mathrm{mL} 81.9 \%$ $\pm 15.1 \% ， 500 \mu \mathrm{g} / \mathrm{mL} \quad 84.9 \% \pm 9.0 \%$; $3 \mathrm{~d}: 125 \mu \mathrm{g} / \mathrm{mL} 83.2 \%$ $\pm 15 \%, 500 \mu \mathrm{g} / \mathrm{mL} 84.6 \pm 13.7 \%$; $5 \mathrm{~d}: 125 \mu \mathrm{g} / \mathrm{mL} \mathrm{86.6 \% \pm 6.0 \% ,}$ $500 \mu \mathrm{g} / \mathrm{mL} \quad 84.4 \% \pm 7.4 \% ; \quad 7 \mathrm{~d}: \quad 125 \mu \mathrm{g} / \mathrm{mL} \quad 82.5 \% \pm 14.3 \%$, $500 \mu \mathrm{g} / \mathrm{mL} \mathrm{88.2 \% \pm 5.6 \% ).}$

\section{Phagocytosis}

We have previously shown that intracellular bevacizumab reduces the phagocytic capacity of RPE cells. ${ }^{9}$ In this study, cells positive for intracellular aflibercept displayed a significantly diminished phagocytosis of opsonised latex beads compared to untreated control (control: $42.8 \pm 4.3$ beads/cell; aflibercept: $28.3 \pm 2.9 ; \mathrm{p}<0.001)$. No differences between aflibercept-treated cells and bevacizumab-treated cells $(30.2 \pm 5.2$ beads/cell $)$ were found (figure 4).

\section{DISCUSSION}

We investigated the effect of aflibercept on the RPE physiology, focusing on toxicity, wound healing, intracellular uptake and phagocytosis.
In a recently published paper, ${ }^{15}$ the toxicity of aflibercept on several ocular cells, including the RPE cell line Arpe19, was tested. No toxicity was found in MTT assay or calcein stain up to a concentration of $1 \mathrm{mg} / \mathrm{mL}$ for $24 \mathrm{~h}$. In another study, the toxicity of aflibercept up to a concentration of $2 \mathrm{mg} / \mathrm{mL}$ up to $72 \mathrm{~h}$ was investigated, using MTT assay, crystal violet staining and caspase $3 / 7$ activation. No toxicity was seen. Our data correspond to these findings, as no toxic effect of aflibercept at a concentration of $500 \mu \mathrm{g} / \mathrm{mL}$ after $24 \mathrm{~h}$ or 7 days was found on primary porcine RPE cells in an MTT assay or a trypan blue exclusion assay. However, we did find a concentrationdependent effect on wound healing, as seen in a scratch assay of confluent primary RPE cells, which was seen at a concentration of $500 \mu \mathrm{g} / \mathrm{mL}$, but not $125 \mu \mathrm{g} / \mathrm{mL}$ aflibercept. As we tested aflibercept, bevacizumab and ranibizumab at $125 \mu \mathrm{g} / \mathrm{mL}$ and at their clinically relevant concentrations, we found that bevacizumab displayed a similar concentration dependent effect seen at $250 \mu \mathrm{g} / \mathrm{mL}$ but not at $125 \mu \mathrm{g} / \mathrm{mL}$. The clinically relevant dose of ranibizumab $(125 \mu \mathrm{g} / \mathrm{mL})$ did not exhibit any effect on wound healing. As all tested concentrations should be sufficient to completely block VEGF in the RPE cell culture supernatant, ${ }^{11}$ other possible effects of high concentrations of aflibercept or bevacizumab may be responsible, and it may be connected to the intracellular uptake of these substances (see below). The impairment of wound healing by aflibercept may indeed constitute an adverse effect of this drug which may be of clinical consequences. Peripheral RPE cells are able to migrate and divide in order to replace deceased RPE cells in the retina. ${ }^{16}$ Moreover, laser therapy induces wound-healing reactions in RPE cells which is considered to be part of the therapeutic effect of laser. ${ }^{17}{ }^{18}$ This may be impaired by high 
Figure 3 Intracellular uptake of aflibercept in RPE cells. RPE cells of second passage were treated with $125 \mu \mathrm{g} / \mathrm{mL}$ and $500 \mu \mathrm{g} / \mathrm{mL}$, respectively, for various time periods (1 h, 4 h, 3 days, 5 days, 7 days). Intracellular aflibercept was detected in immunocytochemistry, using a goat anti-human antibody coupled with AlexaFluor555. Aflibercept can be found in RPE cells $1 \mathrm{~h}$ after stimulation and is still seen after 7 days, the latest investigated time point. Aflibercept is found in vesicles in the cells.

Additionally, after 3 days, a netlike structure can be seen. No differences in cellular pattern or percentage of positive cells can be observed between $125 \mu \mathrm{g} / \mathrm{mL}$ and $500 \mu \mathrm{g} / \mathrm{mL}$ aflibercept (quantification done with $n=6$ independent experiments and 5 slides/ experiment). Significance was determined by student's $\mathrm{t}$ test. $\mathrm{h}=$ hour/ $\mathrm{s}, \mathrm{d}=$ days.
$125 \mu \mathrm{g}$
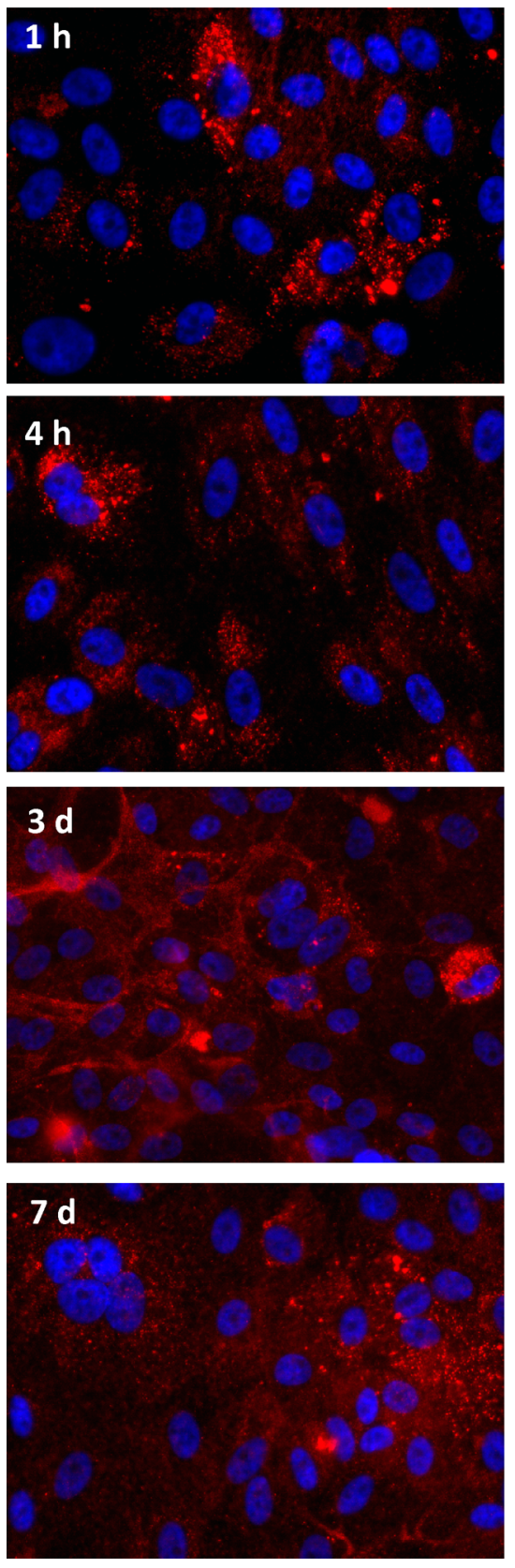

$500 \mu \mathrm{g}$
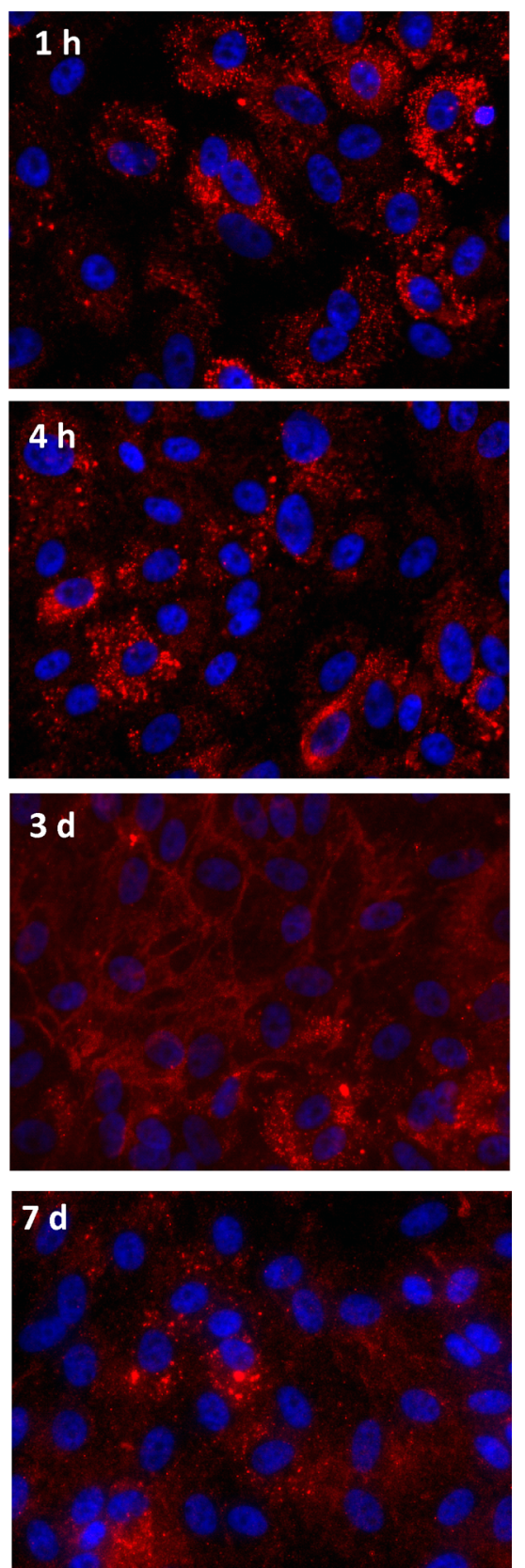

concentrations of aflibercept or bevacizumab. Whether our in vitro findings are of clinical relevance in vivo, however, remains to be seen, especially as the clinically relevant concentrations refers to the intravitreal concentration immediately after injection, and may not reflect the actual concentration reached at the RPE.

We previously have shown that bevacizumab, but not ranibizumab, is taken up and stored by RPE cells. ${ }^{8}$ Recently, this has been confirmed for endothelial cells. ${ }^{10}$ In our study, an intracellular uptake of aflibercept in primary RPE cells can clearly be observed. Not all RPE cells take up aflibercept, which corresponds to the results obtained for bevacizumab. Intracellular aflibercept can be seen for up to 7 days (the last investigated time point), which also corresponds to bevacizumab. ${ }^{8}$ Aflibercept is seen in vesicles and, after 3 days, also in a net-like structure. The similarities between aflibercept and bevacizumab indicate that the Fc-part of the molecule may be involved in uptake and intracellular trafficking of the molecule. Interestingly, no differences were found between $125 \mu \mathrm{g} / \mathrm{mL}$ and $500 \mu \mathrm{g} / \mathrm{mL}$ aflibercept, indicating that the process is saturable, and that saturation is achieved. Of note, cellular uptake of aflibercept into the RPE cells has very recently been shown in vivo in monkeys. ${ }^{19}$

The uptake of aflibercept has consequences for the physiology of the cells as we see a significant reduction of phagocytosis in cells that incorporated aflibercept. Again, this mirrors the findings observed with bevacizumab and is clearly dependent on the presence of intracellular aflibercept and not on the inhibition of VEGF, as ranibizumab displays no effect on phagocytosis. ${ }^{9}$ As phagocytosis is an important task for the RPE cells in order to remove shed photoreceptor outer segments, ${ }^{20}$ a long-term inhibition of phagocytosis could, in fact, have a deleterious effect on photoreceptor function, as seen in RCS rats and other 


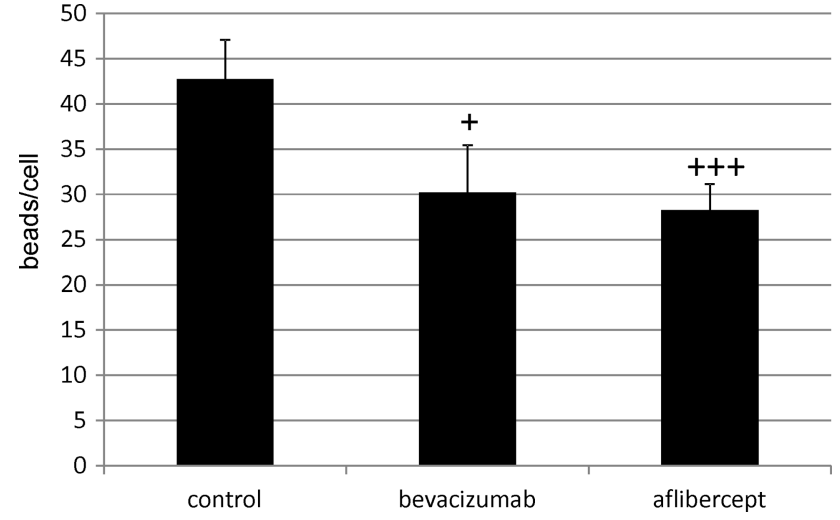

Figure 4 Influence of aflibercept $(500 \mu \mathrm{g} / \mathrm{mL})$ on the phagocytosis of RPE cells. RPE cells of second passage were treated once with $500 \mu \mathrm{g} / \mathrm{mL}$ aflibercept or $250 \mu \mathrm{g} / \mathrm{mL}$ bevacizumab. Phagocytosis was evaluated after 7 days in a phagocytosis assay utilising FITC-labelled beads, treated with a crude extract of photoreceptor outer segments, applied for $4 \mathrm{~h}$ to the cells. The uptake was assessed in a fluorescence microscope. Beads and nuclei of cells displaying intracellular aflibercept, or bevacicumab, respectively, were counted, the ratio determined and compared to untreated control (8 pictures per slide). Cells positive for intracellular aflibercept displayed a significantly diminished phagocytosis of opsonised latex beads compared to untreated control. No differences between aflibercept-treated cells and bevacizumab-treated cells could be determined. Significance was determined by Student t test. ${ }^{+\prime} p<0.05,{ }^{\prime+++\prime} p<0.001$.

conditions where RPE phagocytosis is impaired. ${ }^{21} 22$ Subtle effects on a cellular level that cumulate in the long-term treatment may not be obvious in the short run, but could cause atrophic changes that would be indistinguishable for the natural course of the disease. However, the relevance of these findings for the in vivo situation remains to be seen, especially as enhanced atrophy could be found after 2 years of anti-VEGF treatment for bevacizumab and ranibizumab, which may even be more pronounced after ranibizumab treatment. ${ }^{23} 24$ In any case, anti-VEGF therapy should be closely monitored and an overtreatment should be avoided.

Signal transduction pathways altered by aflibercept which may convey its effects on RPE cells are not known. A connection may be found in ERK signalling, as ERK signalling is involved in migration and phagocytosis, and aflibercept has been shown to reduce ERK activation in endothelial cells, but the available data are insufficient to draw any conclusion on this matter, and further research needs to be conducted. ${ }^{25-27}$

In conclusion, aflibercept interferes with the physiology of RPE cells, as it impairs wound healing and is taken up into RPE cells, which is accompanied by a reduction of the phagocytic ability, indicating possible adverse effects of aflibercept.

Acknowledgements Parts of the data presented here have been presented at the DOG meeting 2013 and the WOC meeting 2014.

Contributors All authors meet the criteria for authorship. No other contributors are listed.

Funding This research was financially supported by a Novartis research grant.

Competing interests This research was financially supported by a Novartis research grant. AK has been a consultant for and received lecture fees and travel grants by Novartis Pharma.

Provenance and peer review Not commissioned; externally peer reviewed.

\section{REFERENCES}

1 Velez-Montoya R, Oliver SCN, Olson JL, et al. Current knowledge and trends in age-related macular degeneration. Today's and futures treatments. Retina 2013;33:1487-502.

2 Mitchell P, Korobelnik JF, Lanzetta $\mathrm{P}$, et al. Ranibizumab (Lucentis) in neovascular age-related macular degeneration: evidence from clinical trials. $\mathrm{Br} J$ Ophthalmol 2010;94:2-13.

3 Heier JS, Brown DM, Chong V, et al. Intravitreal aflibercept (VEGF Trap-Eye) in wet age-related macular degeneration. Ophthalmology 2012;119:2537-48.

4 Jyothi S, Chowdhury $\mathrm{H}$, Elagouz $\mathrm{M}$, et al. Intravitreal bevacizumab (Avastin) for age-related macular degeneration: a critical analysis of literature. Eye 2010;24:816-24.

5 Harding SP. Neovascular age-related macular degeneration: decision making and optimal management. Eye 2010;24:497-505.

6 Hörster R, Ristau T, Sadda SR, et al. Individual recurrence intervals after anti-VEGF therapy for age-related macular degeneration. Graefes Arch Clin Exp Ophthalmol 2011;249:645-52.

7 Klettner A, Roider J. Treating age-related macular degeneration -interaction of VEGF-antagonists with their target. Mini Rev Med Chem 2009;9:1127-35.

8 Klettner AK, Kruse ML, Meyer T, et al. Different properties of VEGF-antagonists: Bevacizumab but not ranibizumab accumulates in RPE cells. Graefes Arch Clin Exp Ophthalmol 2009;247:1601-8

9 Klettner A, Möhle F, Roider J. Intracellular bevacizumab reduces phagocytotic uptake in RPE cells. Graefes Arch Clin Exp Ophthalmol 2010;248:819-24.

10 Deissler HL, Deissler H, Lang GE. Actions of bevacizumab and ranibizumab on microvascular retinal endothelial cells: similarities and differences. $\mathrm{Br} J$ Ophthalmol 2012:96:1023-8.

11 Klettner A, Roider J. Comparison of bevacizumab, ranibizumab, and pegaptanib in vitro: efficiency and possible additional pathways. Invest Ophthalmol Vis Sci 2008:49:4523-7.

12 Hillenkamp J, Dydykina S, Klettner A, et al. Safety testing of indocyanine green with different surgical light sources and the protective effect of optical filters. Retina 2010:30:1685.

13 Klettner A, Koinzer S, Waetzig V, et al. Deferoxamine mesylate is toxic for retinal pigment epithelium cells in vitro, and its toxicity is mediated by p38. Cutan Ocul Toxicol 2010;29:122-9.

14 Klettner A, Möhle F, Lucius R, et al. Quantifying FITC-labeled latex beads opsonized with photoreceptor outer segment fragments; an easy and inexpensive method of investigating phagocytosis in the retinal pigment epithelium cells. Ophthalmic Res 2011:46:88-91.

15 Ammar DA, Mandava N, Kahook MY. The effects of aflibercept on the viability and metabolism of ocular cells in vitro. Retina 2013:33:1056-61.

16 Al-Hussaini H, Kam JH, Vugler A, et al. Mature retinal pigment epithelium cells are retained in the cell cycle and proliferate in vivo. Mol Vis 2008;14:1784-91.

17 Roider J, Michaud NA, Flotte TJ, et al. Response of the retinal pigment epithelium to selective photocoagulation. Arch Ophthalmol 1992:110:1786-92.

18 Treumer F, Klettner A, Baltz J, et al. Vectorial release of matrix metalloproteinases (MMPs) from porcine RPE-choroid explants following selective retina therapy (SRT): towards slowing the macular ageing process. Exp Eye Res 2012:97:63-72.

19 Julien S, Biesemeier A, Taubitz T, et al. Different effects of intravitreally injected ranibizumab and aflibercept on retinal and choroidal tissues of monkey eyes. $\mathrm{Br} \mathrm{J}$ Ophthalmol 2014;98:813-25.

20 Strauss 0 . The retinal pigment epithelium in visual function. Physiol Rev 2005:85:845-81.

21 Nandrot EF, Dufour EM. Merkt in daily retinal phagocytosis: a history in the making Adv Exp Med Biol 2010;664:133-40.

22 Mustafi D, Kevany BM, Genoud C, et al. Defective photoreceptor phagocytosis in a mouse model of enhanced $\mathrm{S}$-cone syndrome causes progressive retinal degeneration. FASEB J 2011;25:3157-76.

23 Chakravarthy U, Harding SP, Rogers CA, et al. Alternative treatments to inhibit VEGF in age-related choroidal neovascularisation: 2-year findings of the IVAN randomised controlled trial. Lancet 2013;382:1258-67.

24 Grunwald JE, Daniel E, Huang J, et al. Risk of geographic atrophy in the comparison of age-related macular degeneration treatments trials. Ophthalmology 2014:121:150-61.

25 Lassoued W, Murphy D, Tsai J, et al. Effect of VEGF and VEGF Trap on vascula endothelial cell signaling in tumors. Cancer Biol Ther 2010;10:1326-33.

26 Cox D, Greenberg S. Phagocytic signaling strategies: Fc(gamma)receptor-mediated phagocytosis as a model system. Semin Immunol 2001;13:339-45.

27 Huang C, Jacobson K, Schaller MD. MAP kinases and cell migration. J Cell Sci 2004:117:4619-28. 